Atmos. Chem. Phys., 14, 4793-4807, 2014

www.atmos-chem-phys.net/14/4793/2014/

doi:10.5194/acp-14-4793-2014

(c) Author(s) 2014. CC Attribution 3.0 License.

\title{
Processing of biomass-burning aerosol in the eastern Mediterranean during summertime
}

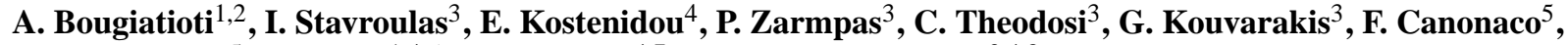 \\ A. S. H. Prévôt ${ }^{5}$, A. Nenes ${ }^{1,4,6}$, S. N. Pandis ${ }^{4,7}$, and N. Mihalopoulos ${ }^{3,4,8}$ \\ ${ }^{1}$ School of Earth and Atmospheric Sciences, Georgia Institute of Technology, Atlanta, GA, USA \\ ${ }^{2}$ National Technical University of Athens, Laser Remote Sensing Laboratory, Zografou, Greece \\ ${ }^{3}$ Environmental Chemical Processes Laboratory, University of Crete, 71003 Crete, Greece \\ ${ }^{4}$ Institute of Chemical Engineering Sciences (ICE-HT), FORTH, Patras, Greece \\ ${ }^{5}$ Laboratory of Atmospheric Chemistry, Paul Scherrer Institute, 5232 Villigen PSI, Switzerland \\ ${ }^{6}$ School of Chemical and Biomolecular Engineering, Georgia Institute of Technology, Atlanta, GA, USA \\ ${ }^{7}$ Department of Chemical Engineering, Carnegie Mellon University, Pittsburgh, USA \\ ${ }^{8}$ Institute for Environmental Research and Sustainable Development, National Observatory of Athens, 15236, Athens, Greece
}

Correspondence to: A. Bougiatioti (kbougiatioti@gmail.com)

Received: 29 August 2013 - Published in Atmos. Chem. Phys. Discuss.: 9 October 2013

Revised: 12 March 2014 - Accepted: 17 March 2014 - Published: 14 May 2014

\begin{abstract}
The aerosol chemical composition in air masses affected by wildfires from the Greek islands of Chios, Euboea and Andros, the Dalmatian Coast and Sicily, during late summer of 2012 was characterized at the remote background site of Finokalia, Crete. Air masses were transported several hundreds of kilometers, arriving at the measurement station after approximately half a day of transport, mostly during nighttime. The chemical composition of the particulate matter was studied by different high-temporal-resolution instruments, including an aerosol chemical speciation monitor (ACSM) and a seven-wavelength aethalometer. Despite the large distance from emission and long atmospheric processing, a clear biomass-burning organic aerosol (BBOA) profile containing characteristic markers is derived from $\mathrm{BC}$ (black carbon) measurements and positive matrix factorization (PMF) analysis of the ACSM organic mass spectra. The ratio of fresh to aged $\mathrm{BBOA}$ decreases with increasing atmospheric processing time and BBOA components appear to be converted to oxygenated organic aerosol (OOA). Given that the smoke was mainly transported overnight, it appears that the processing can take place in the dark. These results show that a significant fraction of the BBOA loses its characteristic AMS (aerosol mass spectrometry) signature and is transformed to OOA in less than a day. This implies that biomass burning can contribute almost half of the organic
\end{abstract}

aerosol mass in the area during periods with significant fire influence.

\section{Introduction}

Organic species represent a significant and often major mass fraction of submicron aerosol. At continental midlatitudes, organic material contributes $\sim 20-50 \%$ of the total fine particulate mass while in tropical forested areas this contribution can be as high as $90 \%$ (Kanakidou et al., 2000; Zhang et al., 2007). During the last few years, factor analysis of measured organic mass spectra from aerosol mass spectrometry (AMS) data has enabled the deconvolution of organic aerosol (OA) to different components based on composition (Zhang et al., 2011). This has provided valuable insights on the source and transformation processes of OA in the atmosphere (Lanz et al., 2008, 2010; Hildebrandt et al., 2010, 2011; Cubison et al., 2011; Aiken et al., 2011; He et al., 2011; Ulbrich et al., 2009). Different components exhibit distinct mass spectra, with the two most common ones being the hydrocarbon-like OA (HOA) and oxygenated OA (OOA) (Zhang et al., 2007). In some cases the OOA component is further resolved into two subtypes that have different degrees of volatility, namely the low-volatility OOA (LV-OOA) and semivolatile OOA 
(SV-OOA) (Jimenez et al., 2009; Ng et al., 2010). Other components are sometimes identified, e.g., biomass-burning OA (BBOA) (Aiken et al., 2009; Cotrell et al., 2008; He et al., 2010; Huang et al., 2011) and cooking OA (COA) (He et al., 2010; Mohr et al., 2009, Allan et al., 2010). The differentiation of the factors is based on the mass spectra of the components, mainly in terms of two mass fragments $\left(\mathrm{CO}_{2}^{+}\right.$at $m / z 44\left(m / z\right.$, mass-to-charge ratio) and $\mathrm{C}_{2} \mathrm{H}_{3} \mathrm{O}^{+}$at $m / z 43$ ) (Ng et al., 2010) and on other characteristic fragments.

Key tracers of BBOA in AMS spectra are the enhanced signals at $\mathrm{m} / \mathrm{z} 60$ and 73 from the ions $\mathrm{C}_{2} \mathrm{H}_{4} \mathrm{O}_{2}^{+}$and $\mathrm{C}_{3} \mathrm{H}_{5} \mathrm{O}_{2}^{+}$(Schneider et al., 2006; Alfarra et al., 2007). The enhanced signal at $m / z 60$ is associated with levoglucosan and other similar species (e.g., mannosan and galactosan). Nevertheless, the sum of levoglucosan, mannosan and levoglucosan alone can account only for around $1 / 10$ or less of the total signal of $m / z, 60$ in BBOA. This indicates that the majority of it originates from different molecules with the same fragmentation pattern as levoglucosan in the AMS (Aiken et al., 2009; Lee et al., 2010b). Given that levoglucosan is a monomer that results from the thermochemical decomposition of cellulose at elevated temperatures in the absence of oxygen, such species may include dimers and trimmers of similar molecules (Cubison et al., 2011). Laboratorybased studies (Hennigan et al., 2010; Hoffmann et al., 2010; Kessler et al., 2010) have estimated an atmospheric oxidation lifetime for levoglucosan in typical conditions that ranges from $15 \mathrm{~h}$ to a few days. Nevertheless, the extent of degradation of the AMS tracer signals $f_{60}$ and $f_{73}$ after emission is not well known. $f_{60}$ has been reported to decrease during photochemical processing of BBOA and from addition of secondary organic aerosol (Huffman et al., 2009). It is unclear whether commonly used tracers persist long enough in aged, atmospheric processed BBOA, to serve as effective markers; $f_{60}$ is currently thought to be a robust tracer for $\mathrm{BB}$ for aging timescales of at least 1 day (Cubison et al., 2011).

The eastern Mediterranean is considered an area of importance for atmospheric aerosol research where aerosols play a significant role in radiative cooling up to five times greater than the warming induced by greenhouse gases (Vrekoussis et al., 2005). During summertime, when enhanced anthropogenic aerosol inflow is combined with limited precipitation and persistent high relative humidity, the total light scattering may be twice of that during wintertime (Kalivitis et al., 2011). The organic fraction during summer accounts for one third of the dry submicron aerosol mass, with organics being highly oxidized (Hildebrandt et al., 2010a). Based on long-term measurements of carbonaceous aerosols in the area, Sciare et al. (2008) demonstrated that every year during two periods (March-April and July-September) there is a high biomass-burning contribution to the aerosol from longrange transport from southern Europe and European countries surrounding the Black Sea.
This study presents high-temporal-resolution measurements in a remote background site in the eastern Mediterranean during late summer (August-September 2012). With the concurrent use of an aerosol chemical speciation monitor (ACSM, Aerodyne Inc.) and a seven-wavelength aethalometer we identified and studied different biomass-burninginfluenced air masses that arrived in the area. The measurements are analyzed to gain insights into the atmospheric processing of BBOA.

\section{Experimental methods}

\subsection{Sampling site and period}

Measurements took place at the Finokalia station $\left(35^{\circ} 32^{\prime} \mathrm{N}\right.$, $25^{\circ} 67^{\prime} \mathrm{E}$; http://finokalia.chemistry.uoc.gr) of the University of Crete, which is part of the Aerosols, Clouds, and Trace gases Research Infrastructure Network (ACTRIS). A detailed description of the site can be found in Mihalopoulos et al. (1997) and Sciare et al. (2003). We focus on periods of intense biomass-burning events that occurred at the Greek islands of Chios, Euboea and Andros, one along the Dalmatian Coast of Croatia that impacted a majority of the Balkan region and one in Sicily. All events took place during August and September of 2012. Air mass origin, trajectory and plume arrival time were estimated by HYSPLIT backtrajectory analysis (www.arl.noaa.gov/ready/hysplit4.html). Locations for each fire are shown in Fig. 1 together with a MODIS image of the Chios fire.

\subsection{Instruments and methods}

High-temporal-resolution measurements were performed with an Aerodyne Research ACSM (Ng et al., 2011a), which measures aerosol mass and chemical composition (ammonium, sulfate, nitrate, chloride and organics) of nonrefractory submicron aerosol particles in real time. The ACSM is designed and built around the same technology as the AMS, in which an aerodynamic particle focusing lens is combined with particle flash vaporization in high vacuum, hard electron impact ionization and final detection of the resulting ions with a commercial quadrupole mass spectrometer. During the measurement period ambient air was drawn into the ACSM by a $\mathrm{PM}_{10}$ aerosol inlet without prior drying. The ACSM particle lens focuses submicron aerosol of $\sim 40-1000 \mathrm{~nm}$ aerodynamic diameter. The $\mathrm{PM}_{10}$ inlet system removes particles that could cause problems for the ACSM inlet (e.g., sea salt, which would cause clogging of the pin hole). The corresponding measurements had a temporal resolution of $30 \mathrm{~min}$. Mass concentrations are calculated with the recommended collection efficiency (CE) of 0.5 for all constituents, apart from sulfate $(0.25)$. The value of 0.25 as $\mathrm{CE}$ for sulfate was based on concurrent $\mathrm{PM}_{1}$ filter analysis for a time period of 4 months (Fig. S2.2 in the Supplement). The obtained CE for sulfate certainly includes the relative 
a)

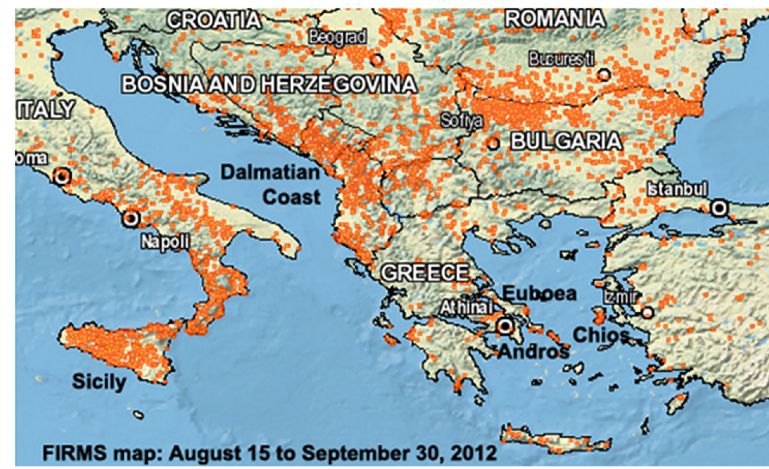

b)

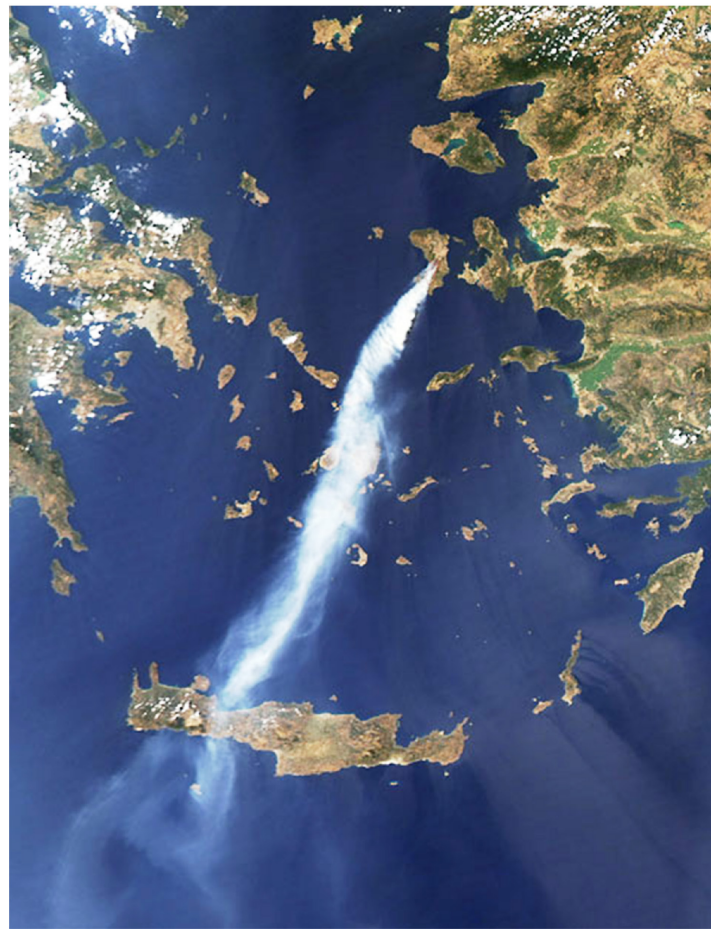

Fig. 1. (a) Occurrence of wildfires as spotted by the Fire Information for Resource Management System (FIRMS) (http://firms. modaps.eosdis.nasa.gov/firemap/) during the whole measurement period (1 August-30 September) with specific locations highlighted in red and (b) MODIS image of the Chios fire (18 August 2012, http://earthobservatory.nasa.gov/IOTD/view.php?id= $78918 \& \mathrm{src}=\mathrm{ve})$.

ionization efficiency (RIE) of sulfate, which is apparently different from the standard RIE of 1.15 proposed by $\mathrm{Ng}$ et al. (2011). The resulting concentrations were compared to those from filter measurements and are discussed in subsequent sections and the Supplement (Sect. S2).

Black-carbon (BC) absorption measurements were conducted with a seven-wavelength aethalometer (Magee Scientific, AE31). Ambient air was drawn into the aethalometer by the same $\mathrm{PM}_{10}$ aerosol inlet as mentioned above, but after passing through a diffusional silica dryer. Samples were obtained every 5 min and were subsequently averaged to 30 min in order to match with the ACSM time intervals.

During the whole measurement period daily $\mathrm{PM}_{1}$ filter samples were collected on precombusted quartz fiber filters. Filters were pre- and post-weighted using a five-digit microbalance (KERN ABT 120-5DM). Samples were analyzed for organic and elemental carbon using an OC/EC analyzer (SUNSET Laboratory Inc.) as well as for water-soluble ions after extraction in ultrasonic bath with nanopure water. The solutions obtained were analyzed by ion chromatography (IC) for anions $\left(\mathrm{Cl}^{-}, \mathrm{Br}^{-}, \mathrm{NO}_{3}^{-}\right.$(nitrate), $\mathrm{SO}_{4}^{2-}$ (sulfate), $\mathrm{C}_{2} \mathrm{O}_{4}^{2-}$ (oxalate)) and cations $\left(\mathrm{K}^{+}, \mathrm{Na}^{+}, \mathrm{NH}_{4}^{+}, \mathrm{Mg}^{2+}, \mathrm{Ca}^{2+}\right.$ ) using the procedure described by Bardouki et al. (2003). Results for organic carbon (OC), sulfate, ammonium and nitrate were compared to ACSM-derived concentrations. As the ACSM provides organic matter $(\mathrm{OM})$ concentrations, the filter-derived OM was calculated by multiplying OC concentrations with a time-dependent conversion factor, which is the corresponding ratio of the average organic molecular mass to the carbon mass for the organic aerosol for the same sampling period for each filter (Sect. 3.3). Particle number distribution was monitored using a custom-made scanning mobility particle sizer (SMPS) equipped with a condensation particle counter (CPC; TSI model 3772) in 5 min-time resolution measuring particles from 9 to $850 \mathrm{~nm}$. The SMPS inlet has a built-in Nafion dryer that lowers relative humidity (RH) to $\sim 30 \%$, therefore aerosol can be considered as almost dry. $\mathrm{O}_{3}$ concentrations and meteorological parameters (wind speed and direction, pressure, temperature, relative humidity) were also continuously monitored.

\subsection{PMF analysis}

The measured mass spectra from the ACSM were deconvolved into different components using the positive matrix factorization (PMF) analysis exploiting the multilinear engine (ME-2) algorithm (Paatero and Tapper, 1994; Paatero 1999). The interface for initiating and controlling the multilinear engine algorithm (ME-2, P. Paatero, University of Helsinki), as well as analyzing the results, was developed at the Paul Scherrer Institute (Canonaco et al., 2013) within the software package Igor Pro Version 6.22A (Wavemetrics Inc., Lake Oswego, OR, USA). The interface is intended to facilitate the analysis of the source apportionment of measured data (Ng et al., 2011b). Briefly, PMF uses a least-squares algorithm to minimize the squared difference between mathematically extracted and the measured data, i.e., the residual weighted by the uncertainty. Here, the measurement error of the ACSM represents the uncertainty. The input organics and organics' error matrices for the analysis are derived automatically from the ACSM data analysis software, using a simple automated procedure (Ulbrich et al., 2009). For ME-2 and PMF the entries in the model solution are fit using a leastsquares algorithm that minimizes iteratively the model uncertainty. For the ACSM data analysis the signals at $m / z 18$ and 
44 are equal in the fragmentation table (Allan et al., 2003; 2004).

\section{Results and discussion}

\section{1 $\mathrm{PM}_{1}$ composition}

ACSM sulfate and ammonium concentrations were on average 19 and $15 \%$ lower than the corresponding $\mathrm{PM}_{1}$ filter measurements $\left(R^{2}=0.8\right.$ and 0.68 respectively) (Supplement Fig. S2). These discrepancies can be attributed to errors and fluctuations in the CE of these species, but also to different cutoff points of the sampling devices. Middlebrook et al. (2012) reported that the CE of the AMS species may be influenced by both elevated aerosol acidity and high relative humidity. Using the parameterization proposed in the aforementioned publication for the effect of high aerosol acidity, we calculated the $\mathrm{NH}_{4} / \mathrm{NH}_{4}$, neutr to be equal to 0.803 $\left(R^{2}=0.67\right)$, where $\mathrm{NH}_{4}$, neutr represents the theoretical ammonium concentration needed to neutralize the inorganic anion mass concentrations. Similar acidic behavior of the aerosol has been observed for the site in previous measurements (Hildebrandt et al., 2010). Organic matter concentrations calculated from $\mathrm{OC}$ analysis $(\mathrm{POM}=\mathrm{OC} * \mathrm{OM} / \mathrm{OC}$, as derived from our dataset, using the estimate of Aiken et al. (2008), Sect. 3.3) and organic concentrations from the ACSM are in good agreement with an average slope of 0.91 and $R^{2}$ of 0.7 . Slightly higher OC concentrations from filter analysis may be due to the adsorption of gaseous organic compounds on the precombusted quartz-fiber filters. The time series of the high-temporal-resolution measurements is shown in Fig. 2a.

We compared the $\mathrm{PM}_{1}$ mass concentrations by adding the ACSM and BC masses with the mass estimated using the SMPS volume (Fig. 2b) and a total density equal to

$\rho=\left[\frac{x_{\mathrm{a} / \mathrm{s}}}{\rho_{\mathrm{a} / \mathrm{s}}}+\frac{x_{\text {org }}}{\rho_{\text {org }}}\right]^{-1}$,

where $x_{\mathrm{a} / \mathrm{s}}$ is the mass fraction of ammonium sulfate, $x_{\mathrm{org}}$ is the mass fraction of the organics, $\rho_{\mathrm{a} / \mathrm{s}}$ is the density of ammonium sulfate $\left(1.77 \mathrm{~g} \mathrm{~cm}^{-3}\right)$ and using an average organic aerosol density $\rho_{\text {org }}$ equal to $1.35 \mathrm{~g} \mathrm{~cm}^{-3}$ as determined by Lee et al. (2010a) for the same site during the summer of 2008. The ACSM concentrations for ammonium and sulfate were corrected based on the filter concentrations. The mass derived from gravimetric measurements of the concurrent daily $\mathrm{PM}_{1}$ filters is also given. The ACSM+BC mass concentrations have an average value of $9.2 \pm 4.8 \mathrm{\mu g} \mathrm{m}^{-3}$, which is in good agreement with the $10.9 \pm 4.2 \mu \mathrm{g} \mathrm{m}^{-3}$ calculated from the SMPS. The difference may be attributed to components that cannot be measured by the ACSM.

The ACSM measurements were then divided into those corresponding to fire events and the rest, based on BC measurements from the aethalometer, the HYSPLIT (HYbrid
Single-Particle Lagrangian Integrated Trajectory) analysis and available satellite pictures. Figure $2 \mathrm{c}$ and $\mathrm{d}$ represent the relative contribution of each constituent to the $\mathrm{PM}_{1}$ mass (sum of the derived constituents) during nonfire and fire events, respectively. During fire events, the contribution of organics and $\mathrm{BC}$ increase substantially while that of sulfate diminishes.

\subsection{Identification of biomass-burning events}

Biomass-burning events were identified by an enhanced BC concentration (Fig. 3). We assume that $250 \mathrm{ng} \mathrm{m}^{-3}$ corresponds to the background concentration for Finokalia during periods where the site is not affected by biomass burning. This limit is consistent with the $213 \pm 34 \mathrm{ng} \mathrm{m}^{-3}$ found by Cristofanelli et al. (2013) in Mt. Cimone, Italy, and comparable to average background levels reported for European, continental background sites (Van Dingenen et al., 2005; Putaud et al., 2004). The average $\mathrm{BC}$ concentration during the measurement period was of $387 \pm 149 \mathrm{ng} \mathrm{m}^{-3}$, with lower values being close to the background value $\left(250 \mathrm{ng} \mathrm{m}^{-3}\right)$. Possible biomass-burning incidents are identified by having BC concentrations at least 2.5 times higher than the Finokalia background (higher than $625 \mathrm{ng} \mathrm{m}^{-3}$ ). This is approximately equivalent to two standard deviations above the average background value. As a second step, locations of possible fire events were identified by FIRMS. The exact location and plume age was calculated by the HYSPLIT back-trajectory analysis.

Five distinct wildfire events affecting the site were identified using the approach described above during the sampling period: a large fire that burned most of the island of Chios (19-21 August); the extensive wildfire at the Dalmatian Coast in Croatia and southern Bosnia-Herzegovina which resulted in smoke plumes that spread all across the Balkans during the period 28-30 August; the smaller fires on the islands of Euboea on 5 September and Andros on 13 September (back trajectories and MODIS images for each can be found in the Supplement); and a fire that took place in the island of Sicily during the period 18-21 September and influenced the site on 21 September.

Based on the back-trajectory analysis and the estimated travel time of the fire plumes, most of the plumes arrived at the site in the early morning hours. While this timing could be coincidental, it is possible that some of these plumes were aloft (above the nighttime mixing layer) and they were mixed downwards reaching the site in the morning.

The above periods were characterized by strong biomassburning ACSM tracers at $m / z 60$ and 73 (Fig. 3a). The signal was considerably weaker for the Sicily fire emissions that traveled the longest before reaching Finokalia. Apart from the ACSM tracers, we also performed source apportionment of BC, based on the approach of Sandradewi et al. (2008). Using an absorption exponent of 1.1 for fossil fuel burning and the average value obtained in the study of 1.86 for pure 
a)

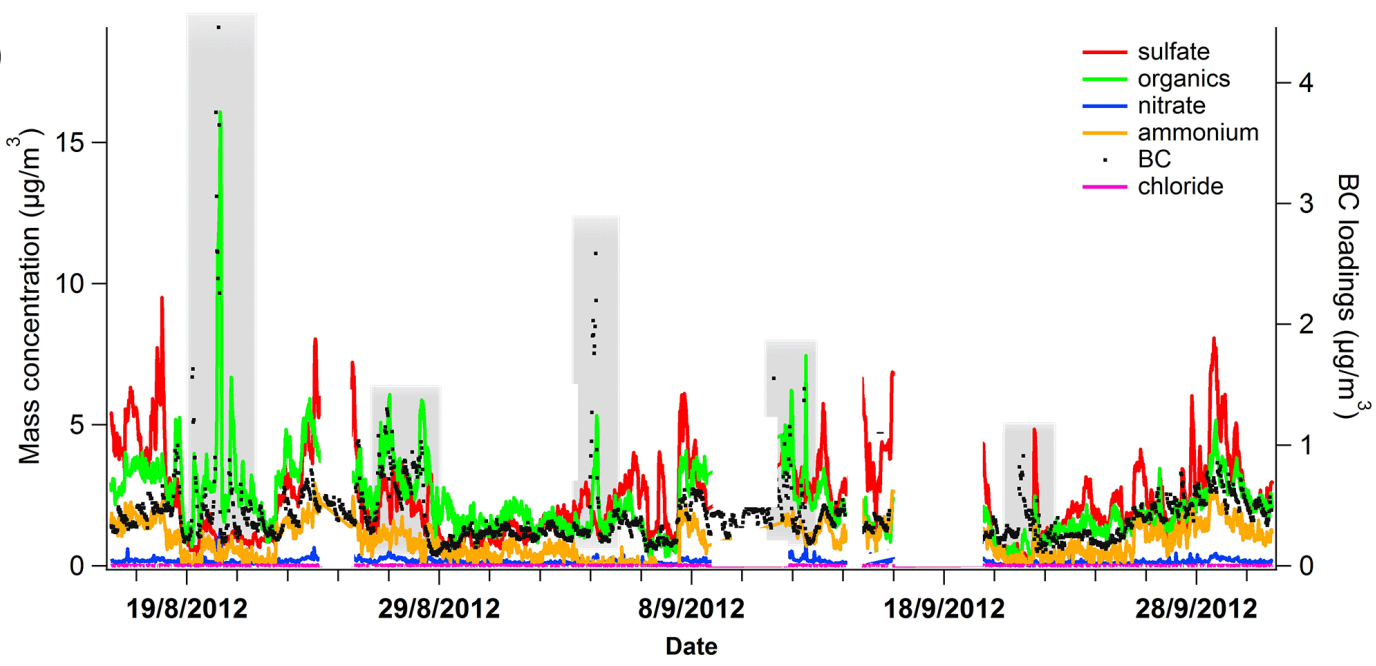

b)

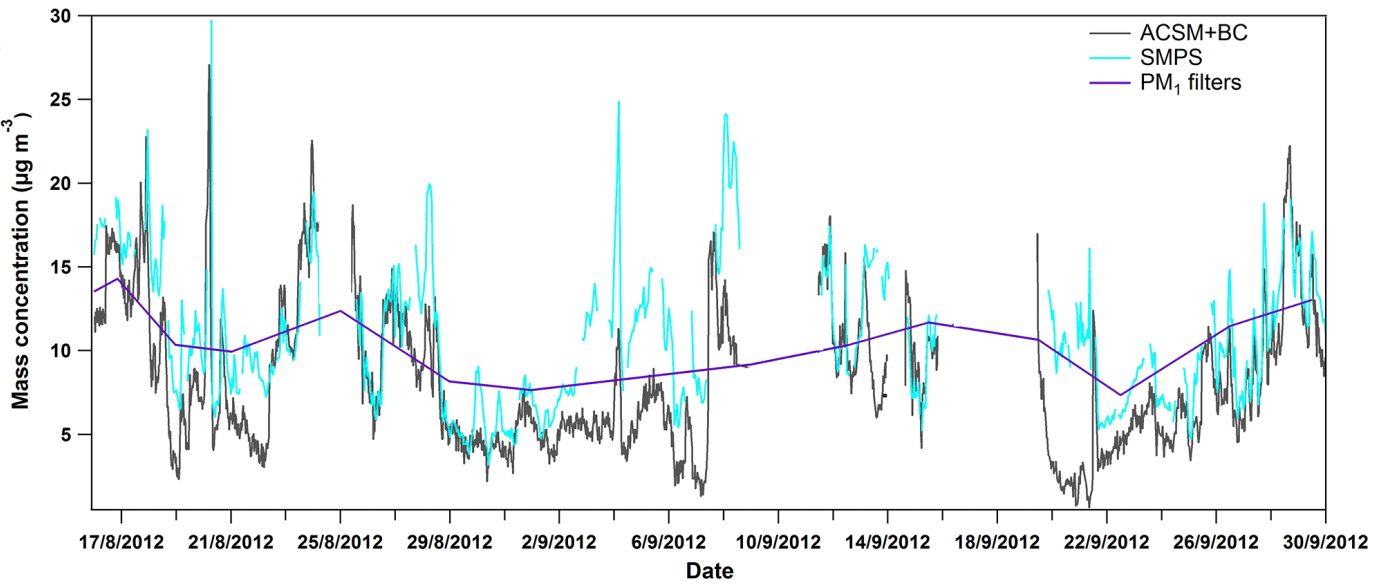

c)
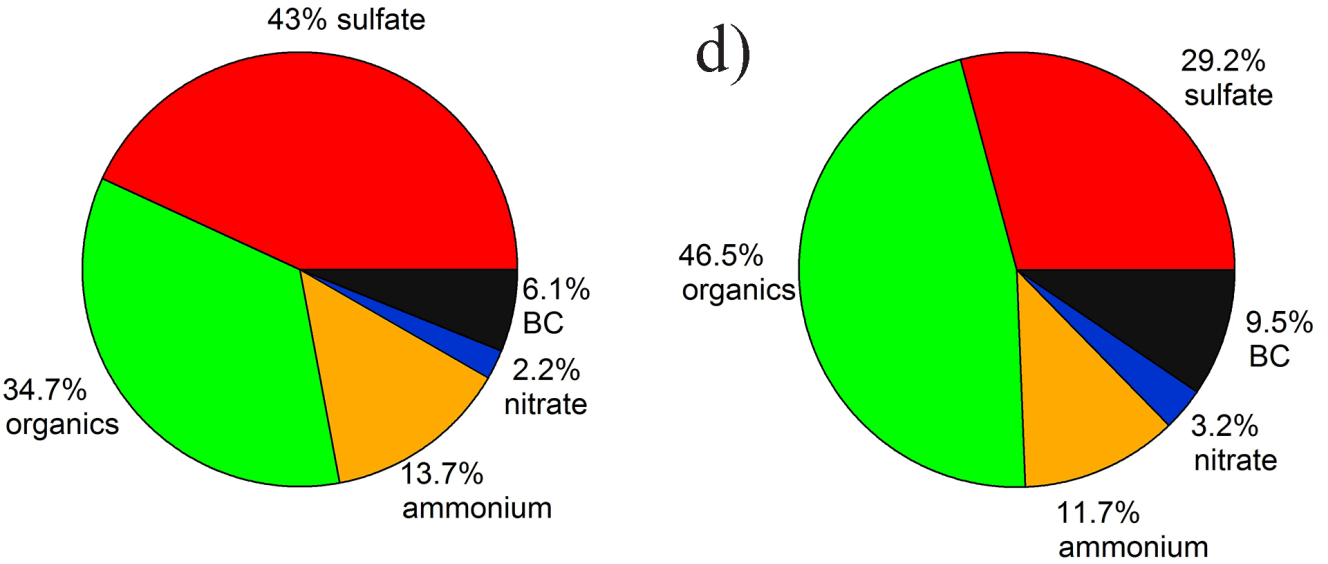

Fig. 2. (a) Time series of concentrations of major $\mathrm{PM}_{1}$ species; (b) comparison of ACSM-derived, SMPS-derived and filter-derived mass time series; $\mathrm{PM}_{1}$ composition during (c) nonfire periods and (d) and fire events. 
a)

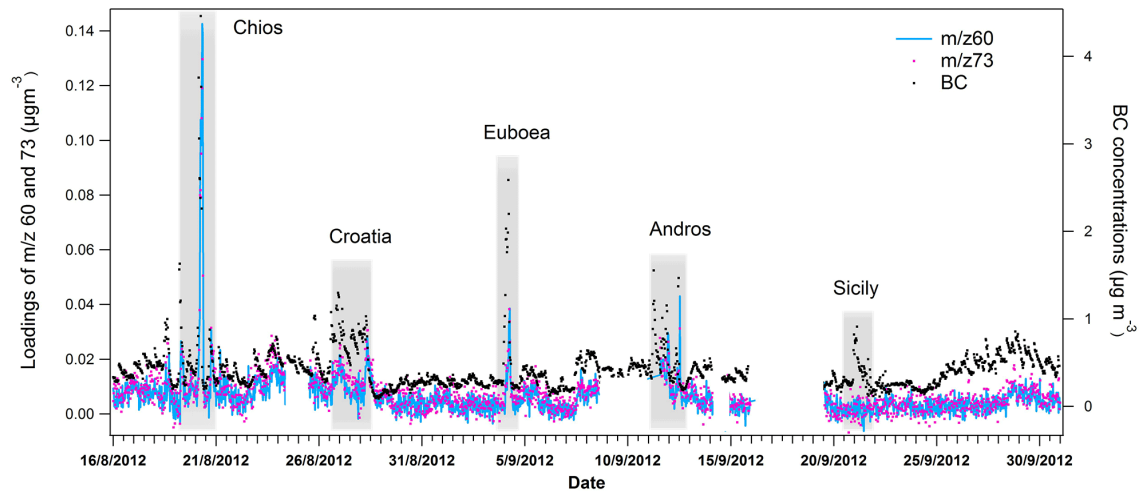

b)

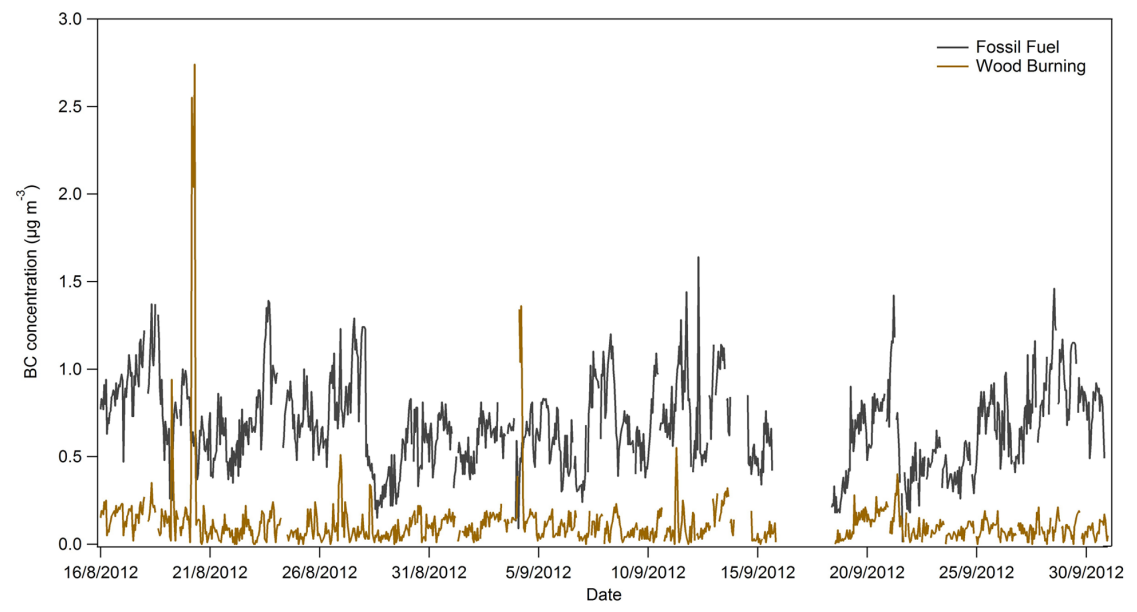

Fig. 3. (a) The time series of the biomass tracer loadings of $m / z 60, m / z 73$ and black carbon; the shaded areas represent the identified fire events and locations. (b) Estimated source apportionment of BC concentrations based on light-absorption measurements.

wood-burning conditions, we calculated the contribution of these components to the total $\mathrm{BC}$ concentrations. The time series of each component is presented in Fig. 3b, where it can be seen that the identified burning events are also depicted by the enhanced contribution of wood-burning BC concentrations.

Finally, BC concentrations were also relatively high towards the end of September (25-30 September), with an average concentration of $535 \pm 109 \mathrm{ng} \mathrm{m}^{-3}$, which is close to 2.5 times higher than the background level for Finokalia. During this period, $\mathrm{BC}$ concentrations build up gradually and the ACSM tracers do not reveal any noticeable variability. In addition, FIRMS does not identify any significant events in the area during the period 25-30 September and the contribution of wood-burning BC is also very low. Therefore these high BC levels are attributed to another source not related to a fire event, therefore this period is not included in the biomass-burning analysis.

\subsection{Elemental composition of organic aerosol}

The ACSM dataset was used to calculate the elemental composition and ratio of organic mass to organic carbon (OM/OC) based on the estimates proposed by Aiken et al. (2008) and $\mathrm{Ng}$ et al. (2011c), as follows:

$\mathrm{O} / \mathrm{C}=(3.82 \pm 0.005) f_{44}+(0.0794 \pm 0.007)$,

$\mathrm{OM} / \mathrm{OC}=(1.26 \pm 0.02) \mathrm{O}: \mathrm{C}+(1.18 \pm 0.001)$,

$\mathrm{H} / \mathrm{C}=(1.01 \pm 0.08)+(6.07 \pm 1.39) f_{43}+$

$(-16.01 \pm 5.34) f_{43}^{2}$,

where $f_{43}$ and $f_{44}$ are calculated as $f_{43}=[\mathrm{m} / z, 43]\left(\mu \mathrm{g} \mathrm{m}^{-3}\right) /$ $\mathrm{C}_{\mathrm{OA}}$, and $f_{44}=[\mathrm{m} / z 44]\left(\mu \mathrm{g} \mathrm{m}^{-3}\right) / \mathrm{C}_{\mathrm{OA}}$ with $\mathrm{C}_{\mathrm{OA}}$ being the total OA mass concentration $\left(\mu \mathrm{g} \mathrm{m}^{-3}\right)$. Based on Aiken et al. (2008) the uncertainty in the raw atomic ratio for $\mathrm{O} / \mathrm{C}$ can be up to $30 \%$, for $\mathrm{H} / \mathrm{C} 10 \%$, and for OM/OC $6 \%$. Biases can also be introduced by the applied fragmentation table. Figure 4 shows the variation of the estimated atomic ratios of $\mathrm{O} / \mathrm{C}$ and $\mathrm{H} / \mathrm{C}$ and the mass ratio of $\mathrm{OM} / \mathrm{OC}$ of the OA during the measurement period, averaging every $2 \mathrm{~h}$, as well as $f_{43}$ vs $f_{44}$ compared to other studies. According to Herringa et al. (2011) the presence of wood-burning POA and its aging SOA are found at the left edge of the triangle. The $\mathrm{O} / \mathrm{C}$ ratio varies between 0.5 and 1.3 , with a mean value of 0.9 , values which are within the observed values of low-volatility and semivolatile OOA $(0.3-1.1 ; \mathrm{Ng}$ et al., 2011c) and dicarboxylic acids (0.4-2.0; Kuwata et al., 
a)

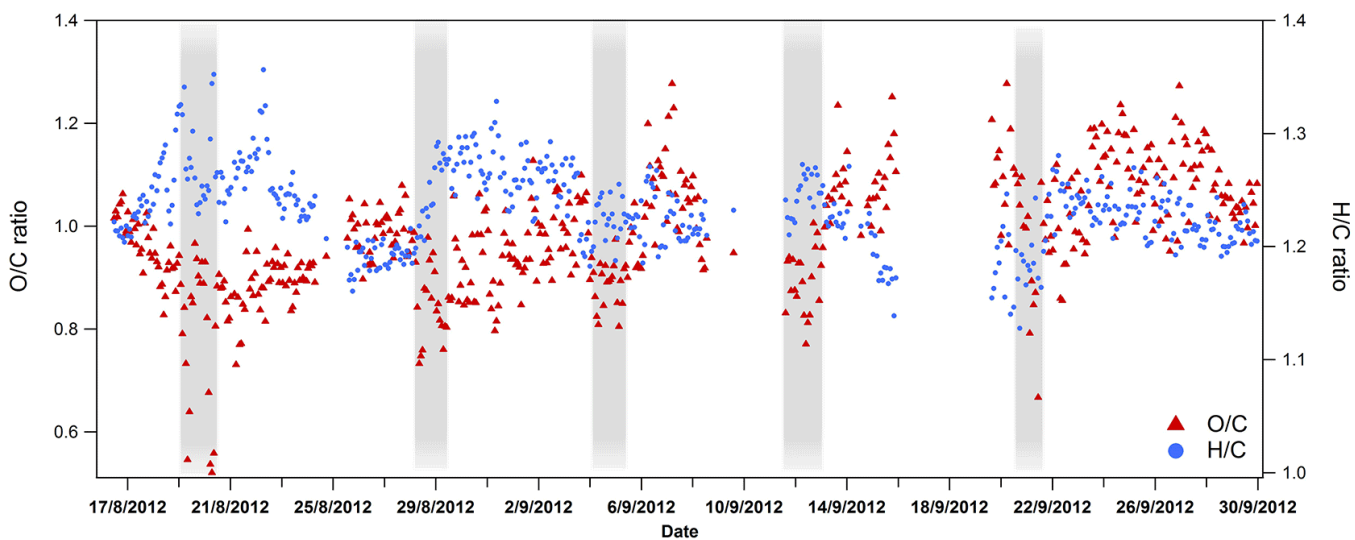

b)

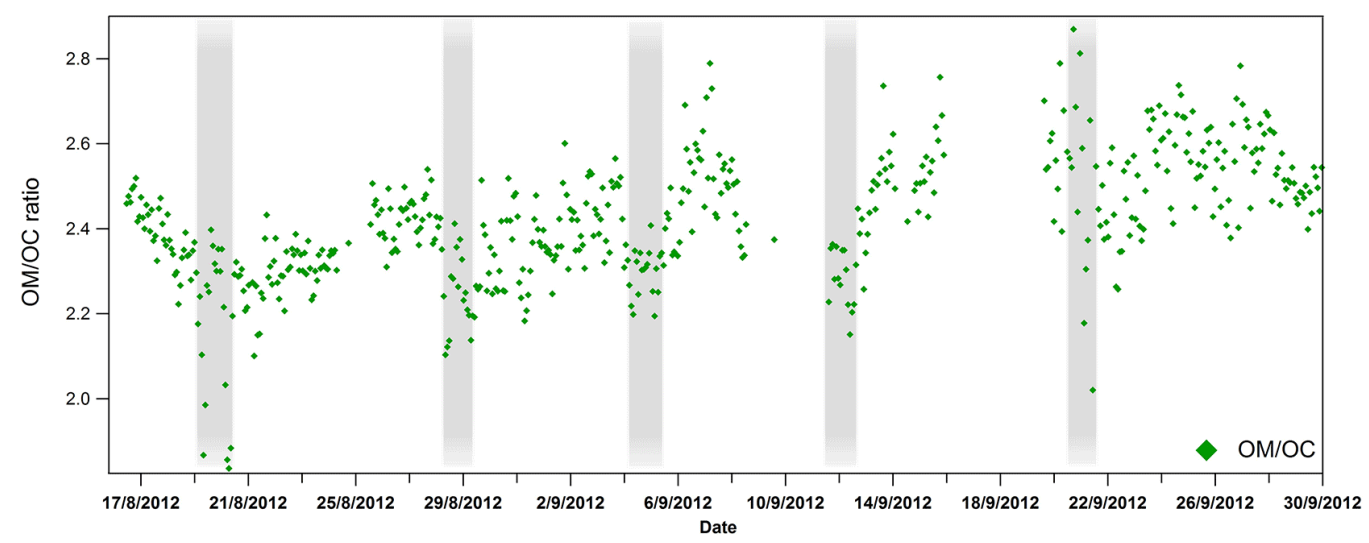

c)

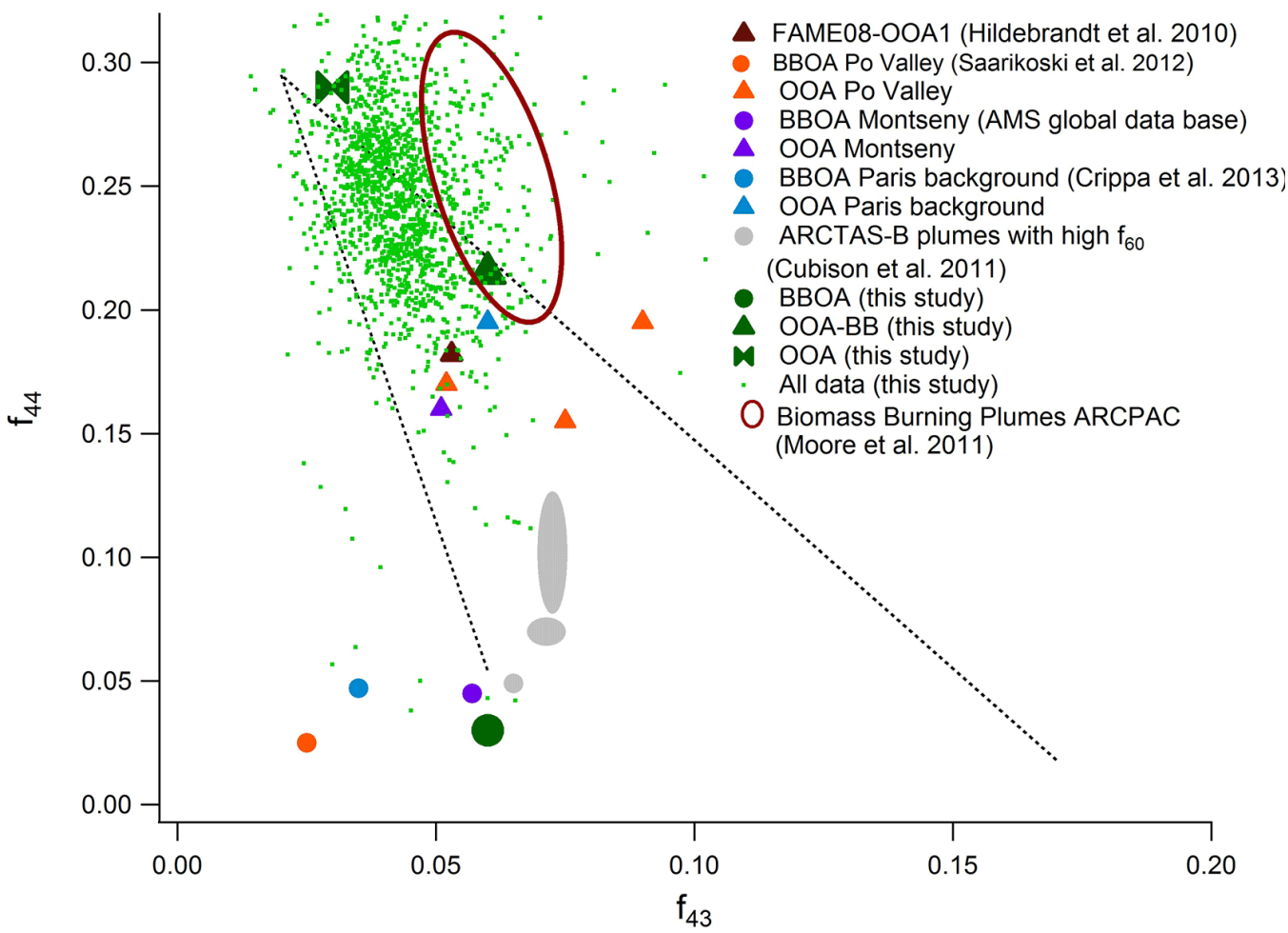

Fig. 4. Time series of atomic ratios of $\mathrm{O} / \mathrm{C}$ and $\mathrm{H} / \mathrm{C}$ (a), the variation of the mass ratio of $\mathrm{OM} / \mathrm{OC}$ (b), and the fractional signals $f_{43}$ and $f_{44}$ of biomass-burning and oxygenated organic aerosol in our study and other studies (c). 
2013). For the same region, Hildebrandt et al. (2010a) estimated an $\mathrm{O} / \mathrm{C}$ of 0.8 for a sunny May period, corresponding to an average $f_{44}$ of $18.2 \%$. The higher $\mathrm{O} / \mathrm{C}$ value found in this study can be attributed to the higher contribution of $f_{44}$ $(23.3 \%)$. The $\mathrm{H} / \mathrm{C}$ ratio varies in a range of 1.1-1.3, with a mean value of 1.2. The $\mathrm{O} / \mathrm{C}$ ratio is a proxy for the oxidation state and the photochemical age of organic aerosols ( $\mathrm{Ng}$ et al., 2011c; Huang et al., 2011) and thus its variability during the measurement period reflects variations in $\mathrm{OA}$ age at $\mathrm{Fi}$ nokalia. Combining information from both ratios, for most of the cases, lower $\mathrm{O} / \mathrm{C}$ coincides with higher $\mathrm{H} / \mathrm{C}$ and all fire events can be clearly identified in the time series. During the identified fire events both $\mathrm{O} / \mathrm{C}$ and $\mathrm{H} / \mathrm{C}$ have average values of 0.8 and 1.3, respectively. These values are consistent with the presence of less oxidized aerosol than the study average. There are lower-than-average $\mathrm{O} / \mathrm{C}$ ratios around 21 September, when biomass-burning-influenced air masses from Sicily arrived at the station after a travel time of more than $30 \mathrm{~h}$.

The average OM/OC was 2.4 , which is characteristic of a remote background site such as Finokalia and which is within uncertainty of the value of 2.2 found by Hildebrandt et al. (2010b) and the value of 2.1 used by Sciare et al. (2005) to convert OC to POM for mass reconstruction during the MINOS summer campaign. These very high values of OM/OC reflect the highly oxidized nature of organic Eastern Mediterranean aerosol, which during the middle of the summer is in fact even more oxidized than found by Hildebrandt et al. (2010a) for the same site during late spring and early summer.

\subsection{Organic aerosol source apportionment using PMF}

The PMF analysis of the ACSM OM mass spectra (MS) acquired during the measurement period was performed investigating solutions using 1-4 factors. The two-factor solution resulted in a mixed processed BBOA profile and an OOA profile. The mixed processed BBOA factor had characteristics of both BBOA, such as signal at $m / z 57,60$ and 73, but also of OOA, with pronounced signal at $\mathrm{m} / z 28$ and 44. It correlates well with both $\mathrm{BC}$ and nitrate $\left(R^{2}=0.6\right.$ and 0.74 , respectively) but poorly with sulfate. Its diurnal variability coincides mostly with the arrival time of biomass-burningladen air masses. Its $\mathrm{O} / \mathrm{C}$ was 0.49 suggesting oxygenated BBOA. When compared to reference mass spectra it correlated relatively well with BBOA $\left(R_{\text {pearson }}=0.76\right)$ but mostly with OOA $\left(R_{\text {pearson }}=0.97\right)$. In order to separate the mixed behavior of this processed BBOA profile we used the threefactor solution. The PMF solutions with four factors resulted in split factors, without identifying a unique factor profile. The splitting behavior was affirmed by poor correlation with tracer species and by mass spectra that appear also to be split between factors.

The three-factor solution was selected for having good correlation with tracer species while displaying distinct diurnal variation, factors have MS features that compare well to ref- erence mass spectra. The stability of the solution was tested by initializing the algorithm of the analysis from 20 different starting points ("seeds") and results showed very little variability, with no unexplained mass observed. Similar results were also obtained by rotating the obtained solution of the model using $f_{\text {peak }}$ runs. Details about the PMF for all cases can be found in the Supplement Sect. 4.

The three factors correspond to fresh BBOA, an OOA component associated with biomass burning (OOA-BB) and a more oxidized OOA. Figure 5 shows the mass spectra of the three factors and the time series of each factor associated with external reference time series. The BBOA, OOA-BB and OOA accounted on average for 18,30 and $52 \%$ of the organic mass, respectively. The average diurnal profile of each factor is also depicted in Fig. 5, where the peak of the BBOA factor coincides with arrival times of smoke-influenced air masses during early morning hours. The diurnal profile of OOA-BB shows an increase in the concentrations between 05:00 and 10:00 local time (UTC/GMT +3) due to the arrival of the fire plumes, which causes the larger variability of the OOA-BB levels during this early morning period.

The OOA diurnal profile (which is very similar to the sulfate one) suggests that there is still chemistry and production of both sulfate and OOA near the site and that the corresponding conversion of organic compounds to OOA and sulfur dioxide to sulfate has not been completed. This chemical processing together with vertical exchange processes could explain the observed average variability. A similar diurnal profile has also been reported by Hildebrandt et al. (2010) in an earlier study in the same area during a similar time period, for the more oxidized, identified organic component. The identified factors were also examined for their mass spectra signatures, their correlation with reference mass spectra and also with other characteristic time series that justify their behavior.

The BBOA component had the characteristic markings of biomass-burning aerosol, which are enhanced signals at $\mathrm{m} / \mathrm{z} 60$ and 73 probably from levoglucosan and related compounds (Schneider et al., 2006; Cottrell et al., 2008). It also had prominent peaks at $m / z 27,29,41,43,55,57,77$ and 91 and significant contributions at high $m / z$ s that are indicative of freshly emitted organic aerosol. The $m / z$ 57, which is pronounced in our BBOA mass spectrum, has two possible origins that are biomass-burning relevant, as it can originate from levoglucosan (most probably $\mathrm{C}_{3} \mathrm{H}_{5} \mathrm{O}^{+}$), but it is also a typical fragment of saturated hydrocarbon compounds or of long alkyl chains $\left(\mathrm{C}_{4} \mathrm{H}_{9}^{+}\right)$, therefore it can be a good marker for fresh aerosol (Alfarra et al., 2004; Capes et al., 2008). The fresh BBOA factor in our study had an O/C of 0.2 and an $\mathrm{H} / \mathrm{C}$ of 1.3 , consistent with other observed BBOA (Fig. 4c). The BBOA-factor time series showed good correlation with both the estimated $\mathrm{BC}$ coming from wood burning $\left(R_{\text {pearson }}=0.81\right)$ as well as with nitrate $\left(R_{\text {pearson }}=0.75\right)$ for the whole measurement period and no correlation with sulfate or ammonium. 
a)

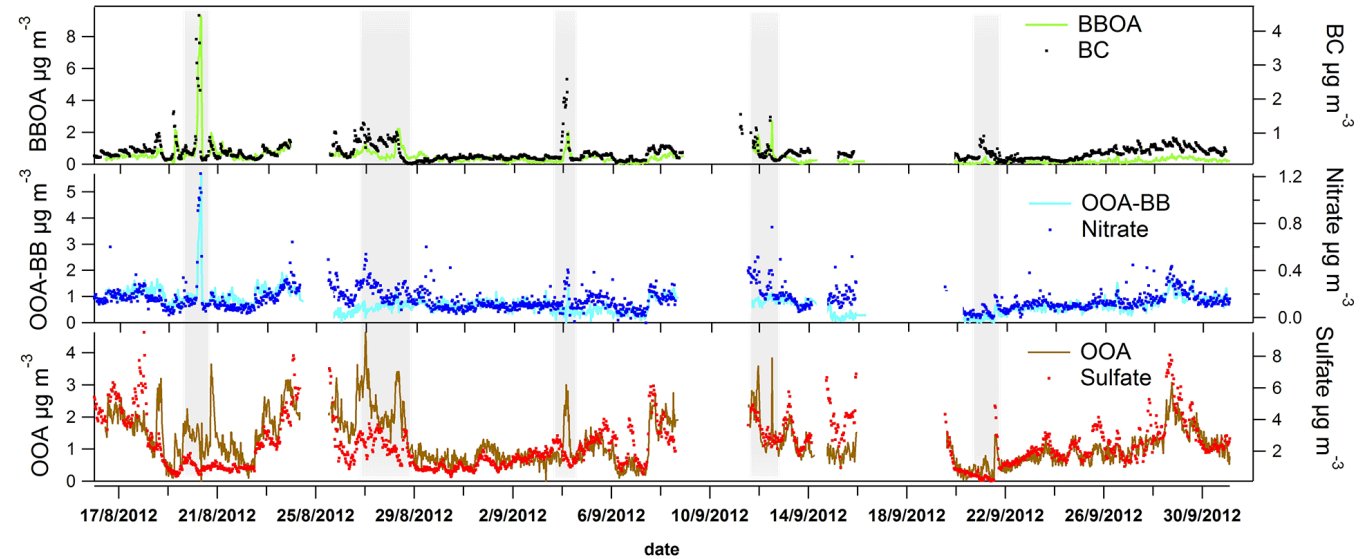

b)

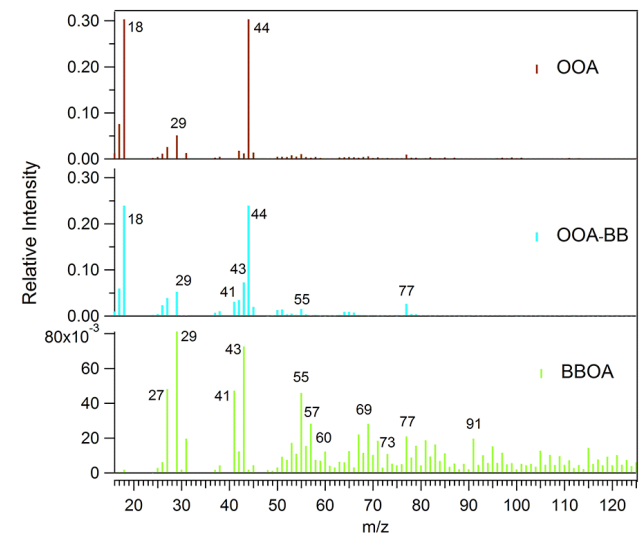

c)

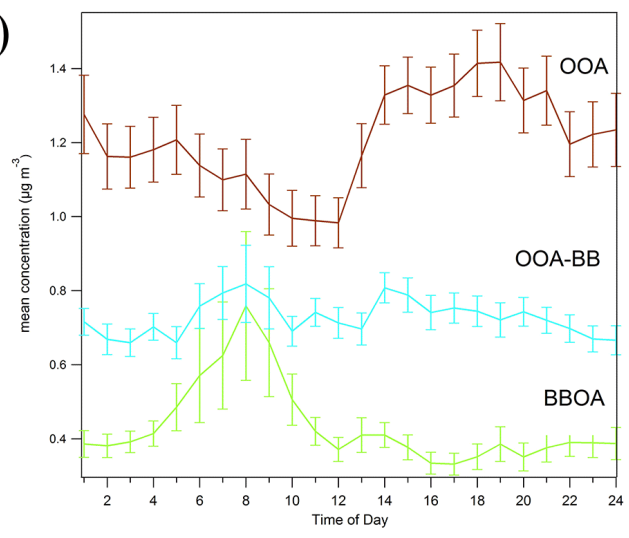

Fig. 5. (a) Time series for the components contributing to OA mass loadings at Finokalia during the measurement period as identified by PMF analysis. For comparison, time traces of BC, nitrate and sulfate are shown. The extracted mass spectra for each factor are shown below the time series (b), along with the diurnal profile of each factor (c). Error bars in the diurnal profiles represent the standard deviation of diurnal variability.

The OOA-BB mass spectrum displayed characteristics of oxidized OA with enhanced signals at $\mathrm{m} / z 18,29$ and 44 . It also had a small signal at $m / z$ 43, implying its potential origin from primary OA. It is possible that processed HOA, which is also apparent from the BC source apportionment (Fig. 3b) can partially contribute to the background concentrations of OOA-BB. Nevertheless it is evident that during the fire events the grand majority of this factor is derived from biomass burning. Its $\mathrm{O} / \mathrm{C}$ was 0.9 and its $\mathrm{H} / \mathrm{C} 1.3$, indicating its processed nature. OOA-BB correlated with nitrate $\left(R_{\text {pearson }}=0.63\right)$ and $\mathrm{BC}\left(R_{\text {pearson }}=0.48\right)$ for the whole measurement period and displayed lower correlation with sulfate and ammonium $(R=0.29$ and 0.38 respectively). If one focuses on the specific period during which the site was affected by the fire plumes, the respective $R$ values between OOA-BB and $\mathrm{BC}$ were $0.74,0.59$, $0.71,0.53$ and 0.45 . The breakdown of correlation suggests that during these periods a fraction of the total variance of the two variables can be explained by the common biomassburning source. Indeed, when using the estimated BC coming from biomass burning the respective values were 0.9,
$0.69,0.79,0.77$ and 0.64 , while for the whole time period the comparison between the OOA-BB with the estimated $\mathrm{BC}$ from wood burning also showed significant correlation $\left(R_{\text {pearson }}=0.69\right)$. OOA-BB also peaked during the fire periods and exhibited similar diurnal variability with the BBOA factor (Fig. 5) further supporting its classification as processed biomass-burning OA.

The OOA component had the characteristics of oxidized organic aerosol, like OOA-BB, but the relative intensity of $\mathrm{m} / \mathrm{z} 18$ and 44 is even more pronounced, indicating more oxidized aerosol, which is also supported by its elevated $\mathrm{O} / \mathrm{C}$ (1.2). The intensity of other fragments in its spectrum is low. This factor correlates well with both sulfate and ammonium ( $R_{\text {pearson }}=0.59$ and 0.62 , respectively). The concentration of OOA peaks during the periods when the site was affected by the fire plumes. This indicates that apart from the multiple possible source origins of OOA, it is also a product of the chemical processing of BBOA in the atmosphere.

Figure 6 shows the similarity (expressed as the angle $\theta$ between the spectra; Kostenidou et al., 2009) between the identified factors in this study and other relative organic aerosol 
a)

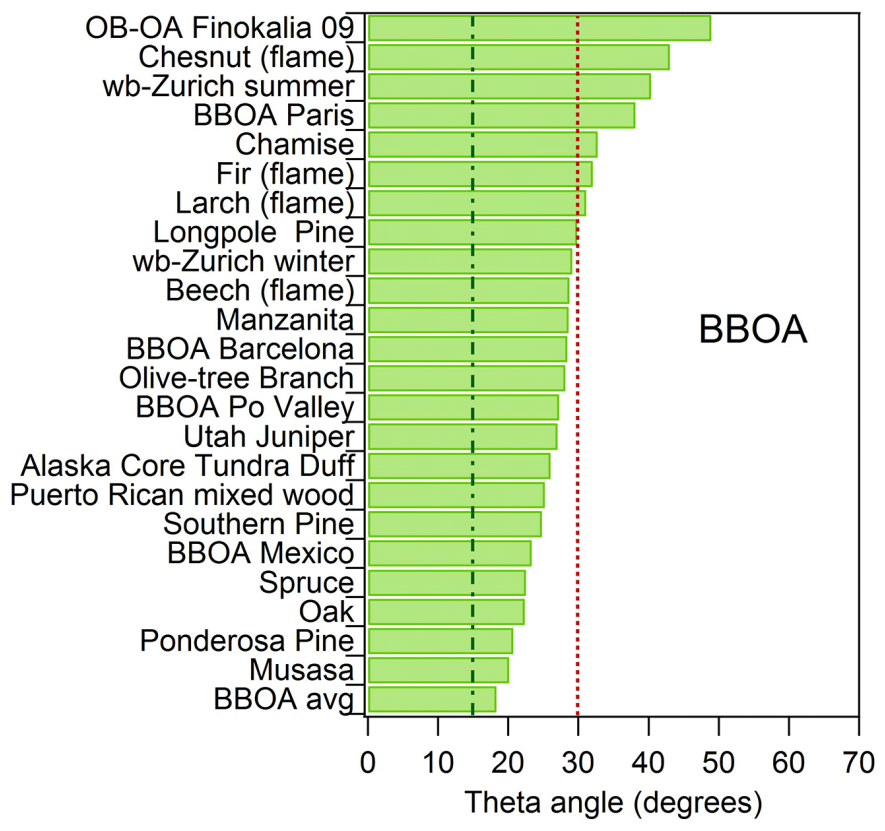

b)

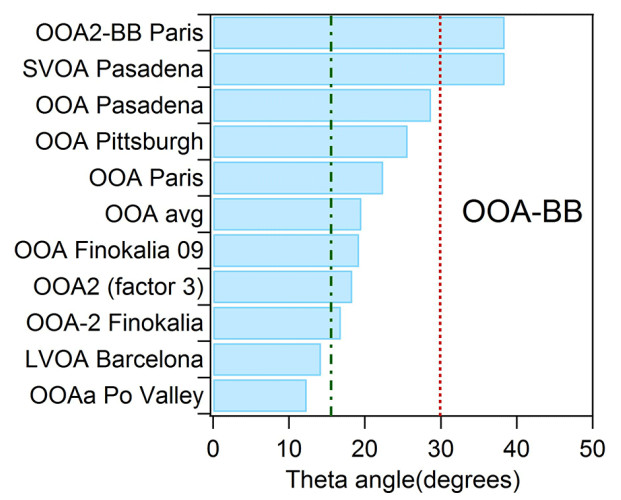

c)

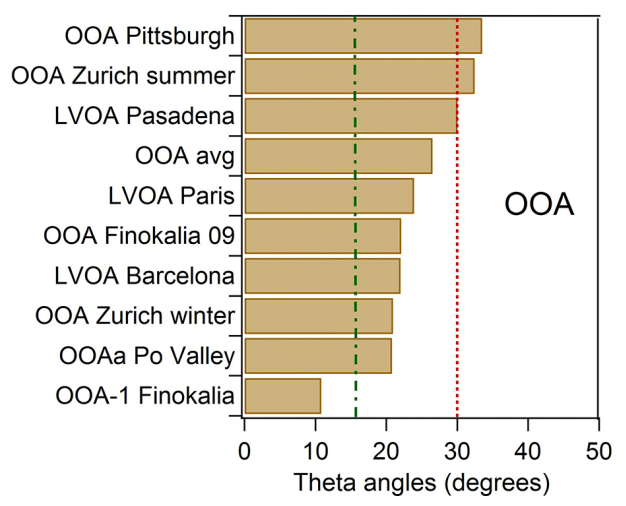

Fig. 6. Comparison (theta angles) between the identified factors of this study with relative organic aerosol spectra (color-coded by PMF solution): (a) fresh biomass-burning factor, (b) aged biomass-burning factor, and (c) oxygenated organic aerosol factor. The dashed lines represent the limits between good, moderate and poor correlation.

spectra found in the AMS mass spectral database (http:// cires.colorado.edu/jimenez-group/AMSsd/). Briefly, spectra that exhibit angles less than $15^{\circ}$ are similar to each other, spectra with angles between 15 and $30^{\circ}$ indicate some similarity but also some important differences, while spectra with theta angles larger than $30^{\circ}$ do not compare well. Our BBOA spectrum correlates well with the average $\mathrm{BBOA}$ of $\mathrm{Ng}$ et al. (2011), obtained by averaging together BBOA mass spectra from two sites (Mexico City and Houston data sets) and has some similarity with the spectra of OA from laboratory burns of pine, oak and spruce (Schneider et al., 2006). The derived BBOA had comparable features with ambient BBOA spectra from Mexico (Aiken et al., 2009), the Po Valley (Saarikoski et al., 2012) and Barcelona (Mohr et al., 2012) $\left(\theta\right.$ between 25 and $\left.30^{\circ}\right)$. The OOA-BB factor correlates well with organic aerosol from the Po Valley and Barcelona, as well as with less oxidized OOA reported for the same sampling site (Finokalia) in past studies during spring and fall (Hildebrandt et al., 2010a; 2011). It does not correlate well with OOA associated with wood burning in fireplaces in Paris during the winter (Crippa et al., 2013) nor with semivolatile OA from Pasadena (Hersey et al., 2011). Finally, OOA correlates well with the more oxidized OOA found for the same site in previous campaigns and resembles the OOA found in Barcelona, Zurich during winter and OOA in the Po Valley.

The contribution of each factor to the OA and the characteristic fragments to the OA mass spectrum of the different fire events is summarized in Table 1. These results are based on separate PMF analysis for each event by selecting the corresponding three-factor solution (SI-4.4). The separate analysis of each event was performed to avoid the a priori constraint that all BBOA spectra were the same and 
Table 1. Relative contribution of each one of the three identified PMF factors to the OA and relative intensity of characteristic markers in each fire event.

\begin{tabular}{llllll}
\hline & Chios & Croatia & Euboea & Andros & Sicily \\
\hline BBOA & 0.4 & 0.16 & 0.29 & 0.29 & 0.18 \\
OOA $_{1}$-BB & 0.32 & 0.28 & 0.37 & 0.27 & 0.25 \\
OOA $_{2}$ & 0.28 & 0.46 & 0.34 & 0.44 & 0.57 \\
$f_{43}$ & 0.08 & 0.07 & 0.06 & 0.03 & 0.03 \\
$f_{44}$ & 0.05 & 0.04 & 0.14 & 0.12 & 0.19 \\
$f_{57}$ & 0.02 & 0.02 & 0.02 & 0.02 & 0.01 \\
$f_{60}$ & 0.01 & 0.01 & 0.01 & 0.01 & 0 \\
$f_{73}$ & 0.01 & 0 & 0.01 & 0.01 & 0 \\
Transport time & $7 \mathrm{~h}$ & $16 \mathrm{~h}$ & $9 \mathrm{~h}$ & $8 \mathrm{~h}$ & $33 \mathrm{~h}$ \\
\hline
\end{tabular}

to quantify their similarities and differences (summarized in Table 1). OOA-BB and OOA mass spectra during each event correlated well with the respective OOA-BB and OOA spectra for the whole measurement period (shown in Fig. 5b) but also with the corresponding spectra of the rest of the events $\left(\theta<15\right.$ and $9^{\circ}$ respectively). $f_{60}$ and $f_{73}$ diminish and $f_{44}$ increases as the transport time of the plume increases. According to Cubison et al. (2011), $f_{60}$ has consistent backgroundlevel values of around $0.3 \%$ in OA with negligible BB influence, with plumes exhibiting a trend toward lower $f_{60}$ with time. This is also the case in our study where the Sicily and Croatia fire events exhibit the lowest values, close to these background levels. We estimated an e-folding time of $12 \mathrm{~h}$ for $m / z 73$ and $28 \mathrm{~h}$ for $m / z 60$ for these fire events. The BBOA fraction in the OA during these events decreases from approximately $40 \%$ for $7 \mathrm{~h}$ of processing to around $15 \%$ for $16 \mathrm{~h}$. The OOA-BB fraction remains relatively constant, while the OOA increases from around 30 to around $60 \%$ as the aerosol ages. These are consistent with a transformation of the BBOA to OOA-BB and then to OOA during the chemical aging of the OA.

Based on these results, the biomass-burning-influenced air masses arriving from Sicily after $30 \mathrm{~h}$ of travel lacked any characteristic BBOA marker. This is an indication that these markers have a finite lifetime, especially during summertime Mediterranean conditions, which combine high temperatures and high insolation periods. $f_{60}$ seems to be a robust $\mathrm{BB}$ tracer only for timescales of up to 1 day from emission. Even with a few hours of atmospheric processing, and mostly during nighttime, the majority of the freshly emitted BBOA is processed and transformed to more oxidized OA, with OOA-BB accounting for $30 \%$ on average of the total organic mass. This is consistent with the observations of aging of fresh biomass-burning OA in plumes over Canada within a few hours after emission (Lathem et al., 2013). This aging was attributed to possible gas-phase oxidation of semivolatile species and also to evaporation of primary semivolatile species (Cubison et al., 2011). Therefore, this aging can be attributed to substantial evaporation of semivolatile species upon dilution of the BB plume but also to heterogeneous or homogeneous reactions that take place during the transport time. This suggests that the contribution of biomass-burning-influenced aerosol can be largely underestimated as a significant part of it may be misidentified as OOA, but not taking into account that it is derived from BBOA.

\section{Summary and conclusions}

High-temporal-resolution measurements were conducted at a remote background site in the eastern Mediterranean with an ACSM and an aethalometer during the period AugustSeptember 2012. During the measurement period $\mathrm{PM}_{1}$ concentrations ranged from 3.2 to $34.2 \mu \mathrm{g} \mathrm{m}^{-3}$ with an average value of $12.2 \pm 4.7 \mu \mathrm{g} \mathrm{m}^{-3}$ with organics and sulfate being the abundant species, each accounting for $\sim 40 \%$ of the $\mathrm{PM}_{1}$. Five discrete biomass-burning events were identified from characteristic tracers in the organics mass spectrum as well as in the $\mathrm{BC}$ time series; and origin of the air masses was verified by backward trajectory analysis. For all the cases the smoke was transported for several hundreds of kilometers. In three events the smoke arrived at the site early in the morning, after around $8 \mathrm{~h}$ of nighttime atmospheric processing. One additional fire event involved air masses with an approximate travel time of $30 \mathrm{~h}$, coming from Sicily. During the fire events the contribution of organics to the total mass increased to almost $50 \%$, with $\mathrm{BC}$ also showing an increase in contribution to almost $10 \%$ of the $\mathrm{PM}_{1}$.

By performing PMF analysis three factors were derived: one having characteristics of biomass burning, one with oxygenated BBOA, and one with highly oxygenated organic aerosol. The BBOA component showed reasonable correlation with reference average BBOA mass spectra while more oxidized OOA correlated well with reference OOA mass spectra. BBOA correlated well with $\mathrm{BC}$ coming from wood burning and nitrate, processed BBOA (OOA-BB) also had high correlation with nitrate and $\mathrm{BC}$ from wood burning and more oxidized OOA correlated well with sulfate and ammonium. More than $80 \%$ of the total organic mass is accounted for by the two oxygenated OOA factors. The OA as a result was highly oxygenated with an overall $\mathrm{O} / \mathrm{C}$ ratio that had a mean value of 0.9 .

Even within 8-9h of travel, and mostly during nighttime, most of the freshly emitted BBOA had been processed and transformed to more oxidized OOA, with processed-BBOA accounting for $30 \%$ on average of the total organic mass. This suggests that the biomass-burning contribution to OA can be misidentified as OOA contribution, therefore underestimating the importance of BBOA, especially during time periods of high biomass-burning activity.

The biomass-burning-influenced air masses arriving from Sicily after $30 \mathrm{~h}$ of travel lacked any characteristic BBOA marker. This is an indication that these markers have a finite lifetime, especially during summertime Mediterranean 
conditions, which combine high temperatures and highinsolation periods. $f_{60}$ seems to be a robust $\mathrm{BB}$ tracer only for timescales of up to 1 day from emission.

\section{Supplementary material related to this article is available online at http://www.atmos-chem-phys.net/14/ 4793/2014/acp-14-4793-2014-supplement.pdf.}

Acknowledgements. The research project is implemented within the framework of the action Supporting of Postdoctoral Researchers of the Operational Program Education and Lifelong Learning (action's beneficiary: General Secretariat for Research and Technology), and is co-financed by the European Social Fund (ESF) and the Greek State. E. Kostenidou and S. N. Pandis acknowledge the support of the FP7 project ATMOPACS. The authors would also like to thank N. L. Ng for her valuable insights on PMF analysis. N. Mihalopoulos acknowledges the support of the FP7 project ACTRIS

Edited by: A. Laaksonen

\section{References}

Aiken, A. C., DeCarlo, P. F., Kroll, J. H., Worsnop, D. R., Huffman, J. A., Docherty, K. S., Ulbrich, I. M., Mohr, C., Kimmel, J. R., Sueper, D., Sun, Y., Zhang, Q., Trimborn, A., Northway, M., Ziemann, P. J., Canagaratna, M. R., Onasch, T. B., Alfarra, M. R., Prevot, A. S. H., Dommen, J., Duplissy, J., Metzger, A., Baltensperger, U., and Jinemez, J. L.: O/C and OM/OC ratios of primary, secondary, and ambient organic aerosols with highresolution time-of-flight Aerosol Mass Spectrometry, Environ. Sci. Technol., 42, 4478-4485, 2008.

Aiken, A. C., Salcedo, D., Cubison, M. J., Huffman, J. A., DeCarlo, P. F., Ulbrich, I. M., Docherty, K. S., Sueper, D., Kimmel, J. R., Worsnop, D. R., Trimborn, A., Northway, M., Stone, E. A., Schauer, J. J., Volkamer, R. M., Fortner, E., de Foy, B., Wang, J., Laskin, A., Shutthanandan, V., Zheng, J., Zhang, R., Gaffney, J., Marley, N. A., Paredes-Miranda, G., Arnott, W. P., Molina, L. T., Sosa, G., and Jimenez, J. L.: Mexico City aerosol analysis during MILAGRO using high resolution aerosol mass spectrometry at the urban supersite (T0) - Part 1: Fine particle composition and organic source apportionment, Atmos. Chem. Phys., 9, 6633-6653, doi:10.5194/acp-9-6633-2009, 2009.

Alfarra, M. R., Prevot, A. S. H., Szidat, S., Sandradewi, J., Weimer, S., Lanz, V. A., Schreiber, D., Mohr, M., and Baltensperger, U.: Identification of the mass spectral signature of organic aerosols from wood burning emissions, Environ. Sci. Technol., 41, 57705777, 2007.

Allan, J.D., Jimenez, J. L., Coe, H., Bower, K. N., Williams, P. I., and Worsnop, D.R.: Quantitative Sampling Using an Aerodyne Aerosol Mass Spectrometer. Part 1: Techniques of Data Interpretation and Error Analysis, J. Geophys. Res.-Atmos., 108, 4090, doi:10.1029/2002JD002358, 2003.

Allan, J. D., Coe, H., Bower, K. N., Alfarra, M. R., Delia, A. E., Jimenez, J. L., Middlebrook, A. M., Drewnick, F., Onasch, T. B., Canagaratna, M. R., Jayne, J. T., and Worsnop, D. R.: Technical Note: Extraction of Chemically Resolved Mass Spectra from
Aerodyne Aerosol Mass Spectrometer Data, J. Aerosol Sci., 35, 909-920, 2004.

Allan, J. D., Williams, P. I., Morgan, W. T., Martin, C. L., Flynn, M. J., Lee, J., Nemitz, E., Phillips, G. J., Gallagher, M. W., and Coe, H.: Contributions from transport, solid fuel burning and cooking to primary organic aerosols in two UK cities, Atmos. Chem. Phys., 10, 647-668, doi:10.5194/acp-10-647-2010, 2010.

Bardouki, H., Liakakou, E., Economou, C., Sciare, J., Smolik, J., Zdimal, V., Eleftheriadis, K., Lazaridis, M., Dye, C., and Mihalopoulos, N.: Chemical composition of size-resolved atmospheric aerosols in the Eastern Mediterranean during summer and winter, Atmos. Environ., 37, 195-208, 2003.

Canonaco, F., Crippa, M., Slowik, J. G., Baltensperger, U., and Prévôt, A. S. H.: SoFi, an IGOR-based interface for the efficient use of the generalized multilinear engine (ME-2) for the source apportionment: ME-2 application to aerosol mass spectrometer data, Atmos. Meas. Tech., 6, 3649-3661, doi:10.5194/amt-63649-2013, 2013.

Capes, G., Johnson, B., McFiggans, G., Williams, P. I., Haywood, J., and Coe, H.: Aging of biomass burning aerosols over West Africa: Aircraft measurements of chemical composition, microphysical properties, and emission ratios, J. Geophys. Res., 113, D00C15, doi:10.1029/2008JD009845, 2008.

Cottrell, L. D., Griffin, R. J., Jimenez, J. L., Zhang, Q., Ulbrich, I., Ziembra, L. D., Beckman, P. J., Sive, B. C., and Talbot, R. W. Submicron particles at Thompson Farm during ICARTT measured using aerosol mass spectrometry, J. Geophys. Res., 113, D08212, doi:10.1029/2007JD009192, 2008.

Crippa, M., DeCarlo, P. F., Slowik, J. G., Mohr, C., Heringa, M. F., Chirico, R., Poulain, L., Freutel, F., Sciare, J., Cozic, J., Di Marco, C. F., Elsasser, M., Nicolas, J. B., Marchand, N., Abidi, E., Wiedensohler, A., Drewnick, F., Schneider, J., Borrmann, S., Nemitz, E., Zimmermann, R., Jaffrezo, J.-L., Prévôt, A. S. H., and Baltensperger, U.: Wintertime aerosol chemical composition and source apportionment of the organic fraction in the metropolitan area of Paris, Atmos. Chem. Phys., 13, 961-981, doi:10.5194/acp-13-961-2013, 2013.

Cristofanelli, P., Fierli, F., Marinoni, A., Calzolari, F., Duchi, R., Burkhart, J., Stohl, A., Maione, M., Arduini, J., and Bonasoni, P. : Influence of biomass burning and anthropogenic emissions on ozone, carbon monoxide and black carbon at the Mt. Cimone GAW_WMO global station (Italy, $2165 \mathrm{~m}$ a.s.1.), Atmos. Chem. Phys., 13, 15-30, doi:10.5194/acp-13-15-2013, 2013.

Cubison, M. J., Ortega, A. M., Hayes, P. L., Farmer, D. K., Day, D., Lechner, M. J., Brune, W. H., Apel, E., Diskin, G. S., Fisher, J. A., Fuelberg, H. E., Hecobian, A., Knapp, D. J., Mikoviny, T., Riemer, D., Sachse, G. W., Sessions, W., Weber, R. J., Weinheimer, A. J., Wisthaler, A., and Jimenez, J. L.: Effects of aging on organic aerosol from open biomass burning smoke in aircraft and laboratory studies, Atmos. Chem. Phys., 11, 12049-12064, doi:10.5194/acp-11-12049-2011, 2011.

He, L.-Y., Lin, Y., Huang, X.-F., Guo, S., Xue, L., Su, Q., Luan, S.J., and Zhang, Y.-H.: Characterization of high-resolution aerosol mass spectra of primary organic aerosol emissions from Chinese cooking and biomass burning, Atmos. Chem. Phys., 10, 1153511543, doi:10.5194/acp-10-11535-2010, 2010.

He, L.-Y., Huang, X.-F., Xue, L., Hu, M., Lin, Y., Zheng, J., Zhang, R., and Zhang, Y.-H.: Submicron aerosol analysis and organic source apportionment in an urban atmosphere in Pearl River 
Delta of China using high-resolution aerosol mass spectrometry, J. Geophys. Res., 116, D12304, doi:10.1029/2010JD014566, 2011.

Hennigan, C. J., Sullivan, A. P., Collett, J. L., and Robinson, A. L.: Levoglucosan stability in biomass burning particles exposed to hydroxyl radicals, Geophys. Res. Lett., 37, L09806, doi:10.1029/2010GL043088, 2010.

Heringa, M. F., DeCarlo, P. F., Chirico, R., Tritscher, T., Dommen, J., Weingartner, E., Richter, R., Wehrle, G., Prévôt, A. S. H., and Baltensperger, U.: Investigations of primary and secondary particulate matter of different wood combustion appliances with a high-resolution time-of-flight aerosol mass spectrometer, Atmos. Chem. Phys., 11, 5945-5957, doi:10.5194/acp-11-59452011, 2011.

Hersey, S. P., Craven, J. S., Schilling, K. A., Metcalf, A. R., Sorooshian, A., Chan, M. N., Flagan, R. C., and Seinfeld, J. H.: The Pasadena Aerosol Characterization Observatory (PACO): chemical and physical analysis of the Western Los Angeles basin aerosol, Atmos. Chem. Phys., 11, 7417-7443, doi:10.5194/acp11-7417-2011, 2011.

Hildebrandt, L., Engelhart, G. J., Mohr, C., Kostenidou, E., Lanz, V. A., Bougiatioti, A., DeCarlo, P. F., Prevot, A. S. H., Baltensperger, U., Mihalopoulos, N., Donahue, N. M., and Pandis, S. N.: Aged organic aerosol in the Eastern Mediterranean: the Finokalia Aerosol Measurement Experiment - 2008, Atmos. Chem. Phys., 10, 4167-4186, doi:10.5194/acp-10-41672010, 2010a.

Hildebrandt, L., Kostenidou, E., Mihalopoulos, N., Worsnop, D. R., Donahue, N. M., and Pandis, S. N.: Formation of highly oxygenated organic aerosol in the atmosphere: Insights from the Finokalia Aerosol Measurement Experiments, Geophys. Res. Lett., 37, L23801, doi:10.1029/2010GL045193, 2010b.

Hildebrandt, L., Kostenidou, E., Lanz, V. A., Prevot, A. S. H., Baltensperger, U., Mihalopoulos, N., Laaksonen, A., Donahue, N. M., and Pandis, S. N.: Sources and atmospheric processing of organic aerosol in the Mediterranean: insights from aerosol mass spectrometer factor analysis, Atmos. Chem. Phys., 11, 1249912515, doi:10.5194/acp-11-12499-2011, 2011.

Hoffmann, D., Tilgner, A., Iinuma, Y., and Herrmann, H.: Atmospheric Stability of Levoglucosan: A Detailed Laboratory and Modeling Study, Environ. Sci. Technol., 44, 694-699, 2010.

Huang, X.-F., He, L.-Y., Hu, M., Canagaratna, M. R., Kroll, J. H., Ng, N. L., Zhang, Y.-H., Lin, Y., Xue, L., Sun, T.-L., Liu, X.-G., Shao, M., Jayne, J. T., and Worsnop, D. R.: Characterization of submicron aerosols at a rural site in Pearl River Delta of China using an Aerodyne High-Resolution Aerosol Mass Spectrometer, Atmos. Chem. Phys., 11, 1865-1877, doi:10.5194/acp-11-18652011, 2011.

Huffman, J. A., Docherty, K. S., Mohr, C., Cubison, M. J., Ulbrich, I. M., Ziemann, P. J., Onasch, T. B., and Jimenez, J. L.: Chemically-Resolved Volatility Measurements of Organic Aerosol from Different Sources, Environ. Sci. Technol., 43, 5351-5357, doi:10.1021/es803539d, 2009.

Jimenez, J. L., Canagaratna, M. R., Donahue, N. M., Prevot, A. S. H., Zhang, Q., Kroll, J. H., DeCarlo, P. F., Allan, J. D., Coe, H., Ng, N. L., Aiken, A. C., Docherty, K. D., Ulbrich, I. M., Grieshop, A. P., Robinson, A. L., Duplissy, J., Smith, J. D., Wilson K. R., Lanz, V. A., Hueglin, C., Sun, Y. L., Tian, J., Laaksonen, A., Raatikainen, T., Rautiainen, J., Vaattovaara, P., Ehn,
M., Kulmala, M., Tomlinson, J. M., Collins, D. R., Cubison, M. J., Dunlea, E. J., Huffman, J. A., Onasch, T. B., Alfarra, M. R., Williams, P. I., Bower, K., Kondo, Y., Schneider, J., Drewnick, F., Borrmann, S., Weimer, S., Demerjian, K., Salcedo, D., Cottrell, L., Griffin, R., Takami, A., Miyoshi, T., Hatakeyama, S., Shimono, A., Sun, J. Y., Zhang, Y. M., Dzepina, K., Kimmel, J. R., Sueper, D., Jayne, J. T., Herndon, S. C., Trimborn, A. M., Williams, L. R.,Wood, E. C., Kolb, C. E., Baltensperger, U., and Worsnop, D. R.: Evolution of organic aerosol in the atmosphere, Science, 326, 1525-1529, doi:10.1126/science.1180353, 2009.

Kalivitis, N., Bougiatioti, A., Kouvarakis, G., and Mihalopoulos, N.: Long term measurements of atmospheric aerosol optical properties in the Eastern Mediterranean, Atmos. Res., 102, 351357, 2011.

Kanakidou, M., Tsigaridis, K., Dentener, F. J., and Crutzen, P. J.: Human-activity-enhanced formation of organic mass fraction of aerosols by biogenic hydrocarbon oxidation, J. Geophys. Res., 105, 9243-9254, 2000.

Kessler, S. H., Smith, J. D., Che, D. L., Worsnop, D. L., Wilson, K. R., and Kroll, J. H.: Chemical Sinks of Organic Aerosol: Kinetics and Products of the Heterogeneous Oxidation of Erythritol and Levoglucosan, Environ. Sci. Technol., 44, 7005-7010, doi:10.1021/es101465m, 2010.

Kostenidou, E., Lee, B.-H., Engelhart, G. J., Pierce, J. R., and Pandis, S. N.: Mass spectra deconvolution of low, medium and high volatility biogenic Secondary Organic Aerosol, Environ. Sci. Technol., 43, 4884-4889, 2009.

Kuwata, M., Shao, W., Lebouteiller, R., and Martin, S. T.: Classifying organic materials by oxygen-to-carbon elemental ratio to predict the activation regime of Cloud Condensation Nuclei (CCN), Atmos. Chem. Phys., 13, 5309-5324, doi:10.5194/acp-13-53092013, 2013.

Lanz, V. A., Alfarra, M. R., Baltensperger, U., Buchmann, B., Hueglin, C., Szidat, S., Wehrli, M. N., Wacker, L., Weimer, S., Caseiro, A., Puxbaum, H., and Prevot, A. S. H.: Source attribution of submicron organic aerosols during wintertime inversions by advanced factor analysis of aerosol mass spectra, Environ. Sci. Technol., 42, 214-220, 2008.

Lanz, V. A., Prévôt, A. S. H., Alfarra, M. R., Weimer, S., Mohr, C., DeCarlo, P. F., Gianini, M. F. D., Hueglin, C., Schneider, J., Favez, O., D'Anna, B., George, C., and Baltensperger, U.: Characterization of aerosol chemical composition with aerosol mass spectrometry in Central Europe: an overview, Atmos. Chem. Phys., 10, 10453-10471, doi:10.5194/acp-10-10453-2010, 2010.

Lathem, T. L., Beyersdorf, A. J., Thornhill, K. L., Winstead, E. L., Cubison, M. J., Hecobian, A., Jimenez, J. L., Weber, R. J., Anderson, B. E., and Nenes, A.: Analysis of CCN activity of Arctic aerosol and Canadian biomass burning during summer 2008, Atmos. Chem. Phys., 13, 2735-2756, doi:10.5194/acp-13-27352013, 2013.

Lee, B. H., Kostenidou, E., Hildebrandt, L., Riipinen, I., Engelhart, G. J., Mohr, C., DeCarlo, P. F., Mihalopoulos, N., Prevot, A. S. H., Baltensperger, U., and Pandis, S. N.: Measurement of the ambient organic aerosol volatility distribution: application during the Finokalia Aerosol Measurement Experiment (FAME2008), Atmos. Chem. Phys., 10, 12149-12160, doi:10.5194/acp10-12149-2010, 2010a.

Lee, T., Sullivan, A. P., Mack, L., Jimenez, J. L., Kreidenweis, S. M., Onasch, T. B., Worsnop, D. R., Malm, W., Wold, C. E., Hao, 
W. M., and Collett, J. L.: Variation of chemical smoke marker emissions during flaming vs. smoldering phases of laboratory open burning of wildland fuels, Aerosol Sci. Technol., 44, 1-5, doi:10.1080/02786826.2010.499884, 2010b.

Mihalopoulos, N., Stephanou, E., Kanakidou,M., Pilitsidis, S., and Bousquet, P.: Troposheric aerosol ionic composition above the eastern Mediterranean area, Tellus B, 49, 314-326, 1997.

Middlebrook, A. M., Bahreini, R., Jimenez, J. L., and Canagaratna, M. R.: Evaluation of composition-dependent collection efficiencies for the Aerodyne Aerosol Mass Spectrometer using field data, Aeorosl Sci. Technol., 46, 258-271, doi:10.1080/02786826.2011.620041, 2012.

Mohr, C., Huffman, J. A., Cubison, M. J., Aiken, A. C., Docherty, K. S., Kimmel, J. R., Ulbrich, I. M., Hannigan, M., and Jimenez, J. L.: Characterization of Primary Organic Aerosol Emissions from Meat Cooking, Trash Burning, and Motor Vehicles with High-Resolution Aerosol Mass Spectrometry and Comparison with Ambient and Chamber Observations, Environ. Sci. Technol., 43, 2443-2449, 2009.

Mohr, C., DeCarlo, P. F., Heringa, M. F., Chirico, R., Slowik, J. G., Richter, R., Reche, C., Alastuey, A., Querol, X., Seco, R., Peñuelas, J., Jiménez, J. L., Crippa, M., Zimmermann, R., Baltensperger, U., and Prévôt, A. S. H.: Identfication and quantification of organic aerosol from cooking and other sources in Barcelona using aerosol mass spectrometer data, Atmos. Chem. Phys., 12, 1649-1665, doi:10.5194/acp-12-1649-2012, 2012.

Moore, R. H., Bahreini, R., Brock, C. A., Froyd, K. D., Cozic, J., Holloway, J. S., Middlebrook, A. M., Murphy, D. M., and Nenes, A.: Hygroscopicity and composition of Alaskan Arctic CCN during April 2008, Atmos. Chem. Phys., 11, 11807-11825, doi:10.5194/acp-11-11807-2011, 2011.

Ng, N. L., Canagaratna, M. R., Zhang, Q., Jimenez, J. L., Tian, J., Ulbrich, I. M., Kroll, J. H., Docherty, K. S., Chhabra, P. S., Bahreini, R., Murphy, S. M., Seinfeld, J. H., Hildebrandt, L., Donahue, N. M., DeCarlo, P. F., Lanz, V. A., Prévôt, A. S. H., Dinar, E., Rudich, Y., and Worsnop, D. R.: Organic aerosol components observed in Northern Hemispheric datasets from Aerosol Mass Spectrometry, Atmos. Chem. Phys., 10, 46254641, doi:10.5194/acp-10-4625-2010, 2010.

Ng, N. L., Herndon, S. C., Trimborn, A., Canagaratna, M. R., Croteau, P. L., Onasch, T. B., Sueper, D., Worsnop, D. R., Zhang, Q., Sun, Y. L., and Jayne, J. T.: An Aerosol Chemical Speciation Monitor (ACSM) for routine monitoring of the composition and mass concentration of ambient aerosol, Aerosol Sci. Technol., 45, 780-794, 2011a.

Ng, N. L., Canagaratna, M. R., Jimenez, J. L., Zhang, Q., Ulbrich, I. M., and Worsnop, D. R.: Real-time methods for estimating organic component mass concentrations from aerosol mass spectrometer data, Environ. Sci. Technol., 45, 910-916, $2011 \mathrm{~b}$

Ng, N. L., Canagaratna, M. R., Jimenez, J. L., Chhabra, P. S., Seinfeld, J.H., and Worsnop, D. R.: Changes in organic aerosol composition with aging inferred from aerosol mass spectra, Atmos. Chem. Phys., 11, 6465-6474, doi:10.5194/acp-11-64652011, 2011c.

Paatero, P. and Tapper, U.: Positive Matrix Factorization - a Nonnegative Factor Model with Optimal Utilization of ErrorEstimates of Data Values, Environmetrics, 5, 111-126, 1994.

Paatero, P.: The multilinear engine- A table-driven, least squares program for solving multilinear problems, including the n-way parallel factor analysis model, J. Comput. Graph. Stat., 8, 854888, 1999.

Putaud, J.-P., Raes, F., Van Dingenen, R., Bruggemann, E., Facchini, M.C., Decesari, S., Fuzzi, S., Gehrig, R., Huglin, C., Laj, P., Lorbeer, G., Maenhaut, W., Mihalopoulos, N., Muller, K., Querol, X., Rodriguez, S., Schneider, J., Spindler, G., Ten Brink, H., Torseth, K., and Wiedensohler, A.: A European aerosol phenomenology-2: chemical characteristics of particulate matter at kerbside, urban, rural and background sites in Europe, Atmos. Environ., 38, 2579-2595, 2004.

Saarikoski, S., Carbone, S., Decessari, S., Giulianelli, L., Angelini, F., Canagaratna, M., Ng, N. L., Trimborn, A., Facchini, M. C., Fuzzi, S., Hillamo, R., and Worsnop, D.: Chemical characterization of springtime submicrometer aerosol in Po Valley, Atmos. Chem. Phys., 12, 8401-8421, doi:10.5194/acp-12-84012012, 2012.

Sandradewi, J., Prevot, A. S. H., Szidat, S., Perron, N., Lanz, V. A., Weingartner, E., and Baltensperger, U.: Using aerosol light absorption measurements for the quantitative determination of wood burning and traffic emission contributions to particulate matter, Environ. Sci. Technol., 42, 3316-3323, 2008.

Sciare, J., Bardouki, H., Moulin, C., and Mihalopoulos, N.: Aerosol sources and their contribution to the chemical composition of aerosols in the Eastern Mediterranean Sea during summertime, Atmos. Chem. Phys., 3, 291-302, doi:10.5194/acp-3-291-2003, 2003.

Sciare, J., Oikonomou, K., Cachier, H., Mihalopoulos, N., Andreae, M. O., Maenhaut, W., and Sarda-Estève, R.: Aerosol mass closure and reconstruction of the light scattering coefficient over the Eastern Mediterranean Sea during the MINOS campaign, Atmos. Chem. Phys., 5, 2253-2265, doi:10.5194/acp-5-2253-2005, 2005.

Sciare, J., Oikonomou, K., Favez, O., Liakakou, E., Markaki, Z., Cachier, H., and Mihalopoulos, N.: Long-term measurements of carbonaceous aerosols in the Eastern Mediterranean: evidence of long-range transport of biomass burning, Atmos. Chem. Phys., 8, 5551-5563, doi:10.5194/acp-8-5551-2008, 2008.

Schneider, J., Weimer, S., Drewnick, F., Borrmann, S., Helas, G., Gwaze, P., Schmid, O., Andreae, M. O., and Kirchner, U.: Mass spectrometric analysis and aerodynamic properties of various types of combustion-related aerosol particles, Int. J. Mass. Spec., 258, 37-49, 2006.

Ulbrich, I. M., Canagaratna, M. R., Zhang, Q., Worsnop, D. R., and Jimenez, J. L.: Interpretation of organic components from Positive Matrix Factorization of aerosol mass spectrometric data, Atmos. Chem. Phys., 9, 2891-2918, doi:10.5194/acp-9-2891-2009, 2009.

Van Dingenen, R., Putaud, J.-P., Martins-Dos Santos, S., and Raes, F.: Physical aerosol properties and their relation to air mass origin at Monte Cimone (Italy) during the first MINATROC campaign, Atmos. Chem. Phys., 5, 2203-2226, doi:10.5194/acp-52203-2005, 2005.

Vrekoussis, M., Liakakou, E., Koçak, M., Kubilay, N., Oikonomou, K., Sciare, J., and Mihalopoulos, N.: Seasonal variability of optical properties of aerosol in the Eastern Mediterranean, Atmos. Environ., 39, 7083-7094, 2005.

Zhang, Q., Jimenez, J. L., Canagaratna, M. R., Allan, J. D., Coe, H., Ulbrich, I., Alfarra, M. R., Takami, A., Middlebrook, A. M., Sun, Y. L., Dzepina, K., Dunlea, E., Docherty, K., De- 
Carlo, P. F., Salcedo, D., Onasch, T., Jayne, J. T., Miyoshi, T., Shimono, A., Hatakeyama, S., Takegawa, N., Kondo, Y., Schneider, J., Drewnick, F., Borrmann, S., Weimer, S., Demerjian, K., Williams, P., Bower, K., Bahreini, R., Cottrell, L., Griffin, R. J., Rautiainen, J., Sun, J. Y., Zhang, Y. M., and Worsnop, D. R.: Ubiquity and dominance of oxygenated species in organic aerosols in anthropogenically-influenced Northern Hemisphere midlatitudes, Geophys. Res. Lett., 34, L13801, doi:10.1029/2007GL029979, 2007.
Zhang, Q., Jimenes, J. L., Caragaratna, M. R., Ulbrich, I. M., Ng, N. L., Worsnop, D. R., and Sun, Y.: Understanding atmospheric organic aerosols via factor analysis of aerosol mass spectrometry: a review, Anal. Bioanal.Chem., 401, 3045-3067, 2011. 